\title{
ON THE OSTEOLOGY AND RELATIONSHIPS OF PROTOSTEGA.
}

E. C. CASE.

\section{INTRODUCTION.}

THE systematic arrangement of the sea turtles, or Pinnata, has long been a mooted point among zoölogists. Prior to the year 1870 there was practical unanimity in placing Dermochelys near the members of the Cheloniidae. In the year 1871 Cope (1) separated these forms, and placed Dermochelys in a distinct group, Athecae, opposed to and of equal rank with the Cryptodira and Pleurodira. One year later, in discussing the genus Protostega (2) he placed it "near the Sphargidae in the suborder Athecae, and in some points to be approximated to the Cheloniidae." In 1875 he established the family Protostegidae (3), a name he had used two years earlier (4).

The group Athecae was apparently accepted by Gervais in his description of Dermochelys (Sphargis) (5), and the separation of the group was recognized by Seeley (6), who in 1880 placed Dermochelys in a group Dermatochelyidae, of equal rank and value with two opposing groups, Peltochelyidae and Aspidochelyidae.

Döderlein (7) accepted Cope's classification with the addition of the group Trionychoidea, and this group was subsequently adopted by Cope (II). Böttger (29) in 1895 recognized the Athecae. Dollo (8) in I 886 published a paper in which he raised the value of Cope's group Athecae by placing it in opposition to all the remaining Testudines grouped under the name Thecophora. This idea he subsequently defended in two papers which appeared in 1887 (9) and 1888 (10).

Dollo was supported by Smith-Woodward (12), Bernard (18), and by Boulenger, both alone (13) and in collaboration with Günther (14). These later authors substituted, as did Lydekker, (15, I6) the name Testudinata for Dollo's Thecophora. 
In I873 Rütimeyer (17) disregarded Cope's classification of two years previous, and placed Dermochelys among the Pinnata.

In 1886 , the same year as Dollo's first paper, Baur published a note in the Zoologischer Anzeiger (19), in which he claimed that the separation of Dermochelys from the Cheloniidae was absolutely artificial. He maintained his position in papers appearing at intervals from 1888 to 1893 (20-26).

Zittel (27) in his text-book, and later Dames (28), disregarded the group Athecae, the former considering the Dermochelyidae as a family of the Cryptodira.

There are then at present three views as to the position of Dermochelys. (I) It is closely related to the Cheloniidae, being merely a specialized form. (2) It is the sole representative of a group equal in rank to all the remaining Testudines. (3) It is the representative of a group of equal rank with the Trionychoidea, Cryptodira, and Pleurodira. ${ }^{1}$

Paleontology alone can decide which of these theories is correct, and, fortunately, a turtle from the middle cretaceous of Kansas, Protostega Cope, is known, which from its intermediate form affords most valuable evidence in completing the phylogeny of the existing sea turtles. This paper is concerned in describing additional remains of this animal, and discussing its relationships to allied forms.

\section{Description of Protostega and Comparison with Related Forms.}

The material used in the following descriptions of Protostega consists of two specimens, both from the Niobrara cretaceous of Kansas. The first and larger specimen comprises the

1 It may be of interest to give here the synonymy of Dermochelys.

1816: Dermochelys, Blainville, Bull. des Sciences par la Société philomatique de Paris, année 1816, p. II9 (wrongly printed 111). (See Baur's discussion of the names Dermochelys, Dermatochelys, and Sphargis, Zool. Anzeiger, no. 270, 1888.)

1820: Sphargis, Merrem, Versuch eines Systems der Amphibien, p. 19.

1822: Corizedo, Fleming, Philosophy of Zoölogy, vol. ii, p. 27 I.

1828: Scytina, Wagler, Oken Isis, 1828, part 2, p. 86r.

1829: Dermatochelys, Wagler, Nat. Syst. Amphib., S. I33.

1832: Chelyra, Rafinesque, Atlantic Joumal and Friend of Knowledge, vol. i, no. 2, Philadelphia, Summer of 1832, p. 62. 
greater part of the plastron and limbs of a very large individual. The bones are in excellent condition, and the sutures very distinct. There are present the hyoplastra of both sides, the hypoplastron of the left side, and weathered fragments of that of the right, the xiphiplastron of the left side, and the distal end of that of the right, the nuchal and eight peripherals determinable as belonging in series on the left side, and fragments of others, the humeri, scapulae, and coracoids of both sides, and the proximal ends of the radius and ulna (?). The femur of the left side, the pubis and ilium of the same side with the distal end of the ischium, the ischium of the right side with the distal ends of the ecto- and ento-pubis. Several incomplete ribs, Pl. IV.

The second and smaller specimen preserves the humerus, scapula, and coracoid of the left side, a singularly complete pelvis, and some incomplete ribs. The greater part of the skull is in fairly good condition, showing the basi-, supra-, and ex-occipitals, the paroccipital, quadrates, petrosals, quadratojugal, and squamosal, the basisphenoid, pterygoids, and palatines, and the almost perfect lower jaw.

Skull. - The supraoccipital was greatly flattened from side to side in the process of fossilization. The ridge forming the upper edge of the bone slants downward and backward, its distal part is incomplete, though apparently only a small part has been lost. The superior-anterior portion bears a narrow face which slants downward and forward for a considerable distance. These regions are almost identical with the same regions in the Cheloniidae, and are widely different from Dermochelys, where the upper edge of the supraoccipital is almost horizontal, and is broad and rounded. The face on the anterior aspect is broad, horseshoe-shaped, and almost vertical.

The region bearing the articular faces for the exoccipitals, petrosals, and paroccipitals is moderately expanded and is quite solid, showing the absence of any great amount of intercalated cartilage, such as occurs in Dermochelys, where the articular faces are represented by rugose pits, and are not distinguishable one from the other. The articular faces for the petrosal and paroccipital meet on the summit of a ridge running outwardly from the external edge of the anterior semicircular canal. 
This canal is represented by a deep triangular pit, no part of which is covered by processes from the sides.

This condition of the semicircular canal is exactly that of the Cheloniidae, and differs widely from Dermochelys, in which it is roofed by three distinct processes meeting in the middle and leaving three foramina for communication with the other semicircular canals (Pl. V, Fig. I).

The exoccipital of the left side is badly crushed, but is still in sutural union with the paroccipital of the same side, and the two are in connection with the supraoccipital. The exoccipital of the right side is separate and almost perfect. The ascending process for the supraoccipital is short and strong. The descending process is short, and did not reach connection with the pterygoid. The articular face for the paroccipital is deeply excavated. The condylar foramen is near the condylar portion, which is well ossified and free from osseous connection with the same region of the basioccipital. This complete and separate ossification of the condylar region is a point of decided difference between the Cheloniidae and Dermochelys; in the latter the region is almost entirely cartilaginous, and the three bones are weakly anchylosed in old specimens (PI. V, Fig. 2).

The basioccipital is a comparatively broad and short bone with well-ossified condylar portion and strong lateral processes terminating in rugose extremities which extended between the pterygoids and the exoccipitals. The under surface is nearly smooth, and lies in the plane of the horizontal axis of the skull. The articulation for the basisphenoid is confined to its anterior end.

In every particular but that of the ossified condylar portion the basioccipital of Protostega agrees with Dermochelys. In the Cheloniidae the lateral processes are small, and the pterygoid articulates with the exoccipital; this causes the basioccipital to lie largely between the exoccipitals, instead of below them as in Dermochelys. The inferior surface of the basioccipital in the Cheloniidae varies from being almost horizontal to being inclined steeply downward and forward, and the basisphenoid may cover it far back towards its middle (PI. V, Fig. 3 ; $a$, from above; $b$, from below). 
The petrosals are both present in a very perfect condition. They are roughly triangular, and have a strong ridge, partly due to pressure, on the external surface. The external face also shows a deep excavation corresponding to a similar excavation on the antero-interior portion of the quadrate. The union of the sides of these two excavations forms the foramen for the external carotid artery, and probably excluded the paroccipital from any part of the foramen.

The external semicircular canal is represented by a deep pit bridged in its antero-superior region by a bony bar reaching from side to side, and leaving in front of it a foramen for communication with the anterior canal.

The articular face for the basisphenoid is broad and strong.

The formation of the carotid foramen, as well as the nature of the semicircular canal, is typically that of the Cheloniidac. In Dermochelys the paroccipital takes large part in the formation of the foramen, and the pit in the petrosal is entirely free from any bony processes (Pl. V, Fig. 4 ; $a$, from within; $b$, from without).

The paroccipital of the right side is present in almost perfect condition. The bone is elongated and reaches connection with the squamosal, a character which never appears in Dermochelys. The posterior or external half of the posterior semicircular canal is roofed by a bony process pierced by two foramina which communicate with the other canals. This character of the posterior semicircular canal appears in the Chelontidae, and is very different from Dermochelys, where there is a single bony process which does not reach entirely across the canal (Pl. V, Fig. 5).

The basisphenoid is badly crushed, but retains somewhat its original character. It is almost round in outline, with a smooth under surface. The upper face is traversed in a longitudinal direction by two deep grooves. There is no trace of an anteriorly extending rostrum on the thickened anterior end. The smooth under surface appearing largely on the base of the skull, with no trace of a ridge where it meets the basioccipital, is similar to the condition found in Dermochelys, though in that genus the basisphenoid takes much larger part in the 
formation of the base of the skull, and separates the pterygoids for a greater distance than it did in Protostega.

The quadrates are present in excellent condition; they are still connected with the pterygoids, which are in turn united with the imperfect palatines. The articular face for the quadrato-jugal is strongly developed, and stands on the summit of a prominent ridge. The anterior edge is thin and rounded in outline; near its inferior portion there is developed a short, stout process, which fits into a deep groove on the external face of the pterygoid. This process gave attachment to the columellar plates or the cartilage of its lower end. This strong process of the quadrate is present in Dermochelys; in the Cheloniidae it is very slender, and may even be absent as in Lepidochelys.

Near the anterior inferior portion of the inner side lies the groove which in connection with the groove on the petrosal forms the foramen for the external carotid artery.

The condylar face is divided into two parts; one, the posterior, looking slightly upward and backward; the other saddleshaped, and looking almost directly downward. The upper posterior portion of the bone shows a strong face for attachment with the squamosal. The most distinctive feature of the bone, and one which is shared with none of the other sea turtles as far as observed, is the manner of attachment to the pterygoid; the posterior portion of that bone reaches almost to the condylar face, instead of being separated from it by a considerable space. The quadrate stood at almost a right angle to the pterygoid (Pl. V, Fig. 6).

The stapes was comparatively a very large bone. The distal end of one preserved in the stapedial notch of the right quadrate is larger than the same bone in a skull of Dermochelys twice as large as the skull here described.

The pterygoids of both sides are present in fairly good condition, the internal edges only being broken and crushed. They are long, slender bones with rounded external edges, decidedly concave external margins, and with no trace of an ectopterygoid process. The posterior portion articulates far down on the quadrate as described, and the posterior external face shows a 
deep groove running forward and upward which receives the epipterygoid process from the quadrate.

The posterior half is not perforated by a branch of the carotid artery as in the Cheloniidae, nor does any foramen for this artery appear on the back of the skull as in that family. In these points of difference from the Cheloniidae, and in the fact previously mentioned that it is separated from the exoccipitals by the lateral processes of the basioccipital, the pterygoid agrees with Dermochelys (Pl. V, Fig. 6).

The palatines are present in an imperfect condition. The anterior and interior portions are gone, and the whole bone is distorted by pressure; enough remains, however, to show that there were deep choanae located far forwards which were not roofed by the vomer and palatines. This condition of the internal nares is largely that of Dermochelys, in which the choanae are far forward, and are not roofed by the palatines and vomer. The articulation with the maxillaries was by a deep, elongated, triangular region, as in the typical Cheloniidae (Pl. V, Fig. 6).

The vomer is present in a fragmentary condition. It did not have a process descending between the palatines, and helping to roof the choanae, as in the Cheloniidae.

The quadrato-jugal of the right side is triangular in general outline. The posterior edge is concave, and the whole bone is convex from above downwards. The superior edge is narrow, and there is no prolongation of the antero-inferior portion, as in Dermochelys (Pl. V, Fig. 7).

The squamosal of the right side shows a broad concave surface for the upper end of the quadrate. The posterior inferior portion shows no groove as in the Cheloniidae. The anterior portion is thin and expanded.

The mandible is present in a singularly perfect condition, the only parts injured being the posterior portions of the complementaries. It is figured in Pl. V, Fig. 8. The whole jaw resembles very much that of the Cheloniidae.

The dentary is broad from above downwards, with the upper surface slightly concave in the region of the symphysis, and marked by deep pits. The symphysis is broadly triangular, it 
extends farther back on the lower surface than on the upper, and its posterior part is marked by a deep pit. The dentary reaches very nearly to the posterior extremity of the mandible, covering in large part the complementary and the surangular.

The complementary is present and complete; it is largely covered externally by the dentary, which also overlaps the superior margin, and appears on the supero-internal edge. The posterior end rises rather high, and terminates abruptly. Its postero-inferior angle articulates with the angular, and forms a bridge over the cavity in the ramus.

The presplenial. Dr. Baur has drawn my attention to the fact that the element described by him (44) in the jaw of certain pleurodiran turtles (the group Chelyoidea), in the Crocodilia, and in the Lacertilia as the presplenial, also occurs in Protostega and Toxochelys. It is an elongated element articulating with the angular and splenial behind, the dentary below, and the coronary above, occupying the same position as in the Chelyoidea, but extending far forward, and covering the groove on the internal surface of the ramus except in its anterior extent. It is pierced by a foramen near its anterior edge. Its general form and relations are shown in the accompanying figure.

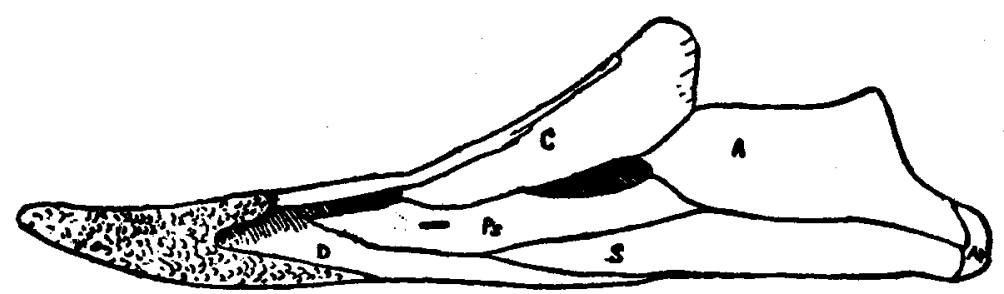

The splenial is distinct from the angular, and appears as a long, splint-like bone reaching forward towards the symphysis. It appears largely on the under surface of the mandible.

The angular is short and broad; it sends a process upwards to meet the complementary. The posterior end shows a large face concave from above downwards, and looking almost directly backwards. It rises above the surangular, concealing it on the interior aspect. 
The surangular is broad and short, joining the complementary by its antero-superior portion. The posterior portion bears an articular face, concave from above downwards, and looking slightly inwards; the external margin of this face ends on a thin ridge.

The articular is well ossified. Its articular face, slightly saddle-shaped, looks backward and upward. The postero-inferior part is rounded, and shows largely on the inferior surface of the mandible. There is no process on the infero-internal portion of the articular, as in the Cheloniidae, and this allows the condylar face of the angular to curve towards the articular at the bottom instead of bending toward the median line of the jaw.

Plastron. - The hyoplastron is a large, heavy plate, thickened in the middle and becoming thin towards the edges, which are extended into long, slender, radiating processes. It is roughly triangular in shape. The antero-internal portion is bent slightly inward, and carried as a strong wing toward the median line, where the terminal processes meet those of the same of the opposite side. The antero-external edge is smooth, free from processes, and concave. The external edge is thickened, and the terminal processes are comparatively short and strong.

The articulation with the hypoplastron was by small and numerous closely interlocking processes amounting almost to a sutural union. The connection occupied nearly half the posterior edge of the bone (Pl. IV).

The hypoplastron is of almost equal size with the hyoplastron. Its general shape is more nearly round, it is furnished with processes on the edges, and those on the posterior internal edge meet those from the same bones of the opposite side. The posterior edge was furnished with two long processes diverging posteriorly, between which the xiphiplastron articulated.

The appended measurements will give an idea of the size of these plates, though the loss of the distal ends of the processes makes exact measurements impossible (PI. IV).

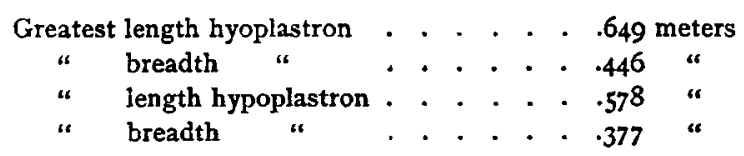


The xiphiplastron is an elongated bone articulating by an interlocking joint between the posterior processes of the hypoplastron. It differs from all sea turtles in the peculiar bending of the bone near its middle; originally directed inwards and backwards, it changes its course abruptly, and is directed inwardly at almost a right angle to its original course. It articulated strongly with the xiphiplastron of the opposite side (Pl. IV and Pl. V, Fig. 9).

There is nothing preserved of the ento- or epi-plastron.

The general shape of the plastron was broadly ovate with the posterior end truncate. The fontanelle was diamond-shaped, and bridged at its anterior and posterior extremities by the lateral processes from the different plates.

The plastron stands midway between that of Dermochelys and that of the Cheloniidae. In Dermochelys the union of the hyo- and hypo-plastra is by the overlapping of the extremities of the slender bones which have lost their radial processes. The xiphiplastron is straight, and articulates by overlapping with the hypoplastron.

In Protosphargis Cap., the plastral bones are more robust than in Dermochelys. The marginal processes are retained to some extent, and the hyo- and hypo-plastra articulate by the interlocking of a few digital processes. The xiphiplastron is straight, and articulates with the hypoplastron by overlapping.

The Cheloniidae have a broad sutural union between the two plates of the plastron. The marginal processes are confined to the distal ends of the bones, leaving the edges near the suture round and smooth. An approximation to this state can be noticed in Protostega, where the marginal processes near the union of the plates are shorter than those on the ends. The nature of the processes varies among the members of the Cheloniidae. In Lepidochelys kempi Garm. they are numerous and irregular, standing on a base that leaves the main body of the plate in a curve, thus forming an oval or rounded fontanelle. In Chelonia there are generally only three processes on the hyoplastron, two of which project from the body of the bone at right angles, and meet across the squarish fontanelle, while the other passes obliquely forward toward the epiplastron. 
The series with Dermochelys at one end, and Chelonia at the other, is marked by a constant variation in the size of the plastral elements, the nature of union of the bones, and the presence and position of the marginal processes.

Carapace. - The ribs are present in fragmentary condition in both specimens. The head was well developed and separated from the costal plate, the proximal end of which was expanded and produced into slender digitations. Examination of a specimen of Chelonia mydas shows that the distance from the point of union of the rib head with the costal plate to the vertebral articulation is greater than the distance from the same point to the neural edge of the costal plate. In Protostega, as these specimens show, the opposite is true even when as in this case the measurements are carried only to the broken ends of the digitations. This shows that there was proportionally less room between the proximal ends of the costal plates in Protostega than in the living sea turtles, and in all probability too little room to allow the presence of neurals. This supposition is further borne out by the digitated proximal ends of the ribs and the entire absence of anything that can be referred to neurals in the known specimens. The expansion of the ribs extends for about half their length (PI. VI, Fig. I9).

The nuchal plate is very peculiar in form, resembling most nearly the nuchal of the soft-shelled turtles. In the present specimen the plate lies directly on the hyoplastra, having been crushed down on them, and has preserved them in their correct relative positions; it is thickened in the middle, becoming thin laterally, and expanded into broad wings. The distal ends of the wings are irregular in outline, and probably articulated weakly with the first peripheral. The upper surface shows two low rugose ridges which run from the center out into the wings, and there disappear. The anterior edge was concave, and beveled from above downward and backward. The posterior edge is continued into a long, slender process running back over the vertebral column. The posterior end of the process is broken off, but apparently only a small portion is missing. There is no process on the under side for articulation with the posterior cervicals (Pl. V, Fig. 10). 
Following are some measurements of the nuchal plate.

Length from tip to tip of wings . . . . . . . . . . . 599 meters

Length from middle of anterior edge to end of posterior process .168 "

Thickness in center . . . . . . . . . . . . . . . . .032 "

Breadth of left wing in broadest part. . . . . . . . .13I "

The peripherals are represented by eight from the left side, which are determinable as belonging in series, and several detached bones whose position is doubtful. The series extends from the second (?) to the ninth. The anterior, which probably joined the nuchal, is unfortunately lost. The second (?) peripheral is slender, concave on its outer edge, and bears no facet for a rib. It articulates strongly with the third. The third is strong and broad, and bears a deep pit for a rib near its external margin. The thickened external margin is turned slightly downward and inwards.

In the succeeding peripherals the length becomes greater than the breadth, and the external margin becomes acute. The turning in of the margin begun on the third becomes broader and broader, shoving the pit before it till in the posterior peripherals it occupies half the under surface of the bones, and its anterior edge underlies the centrally located pit. The inner edges of the peripherals are irregular, and extended into slender processes. Pl. V, Fig. II, shows the upper surface of the fifth and sixth, and gives a good idea of the general shape of the peripherals and their strong articulation one with another. The following measurements are accurate in so far as the broken condition of the inner edge would permit.

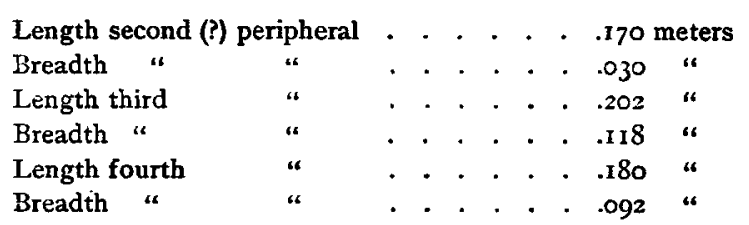

The condition of the carapace of Protostega as described above is heralded in the young of Chelone Benstedii Owen, where the costal plates taper from the proximal to the distal end, and in Allopleuron Baur (Chelone Hoffmani Gray), where the ribs have become very slender and the costalia short and 
broad. In Protosphargis and Dermochelys the rib head is not covered by an expansion of the upper surface of the rib.

The loss of the neurals may find its initial step in the condition of Eosphargis (Chelone gigas Owen). There are in that genus, as described by Lydekker (30), six or seven large plates overlying the ribs; these were considered by Owen in the original description as neurals, but are considered by Lydekker as dermal scutes. It is difficult to see, however, whence the "median dorsal row of large carinated scutes" may have taken their origin if they are not neural plates which have lost connection with the vertebrae, and become laterally expanded so as to cover the ribs in part. This loss of connection between the neurals and vertebrae may be observed in the recent Lepidochelys kempi Garm., where I, 2, 3, and also 8 are free $(2 \mathrm{I})$.

The strong peripherals of Protostega were possibly present in Eosphargis (30), and peripherals have been observed in Protosphargis (31). They were very slender in Protosphargis, and were considered by the original describer as phalanges, but were later shown by Baur to be peripherals.

Most of the Cheloniidae have the typical number, eleven, but Thalassochelys and Lepidochelys have more, the number being varied by the introduction of one or two extra plates between the $I$ and 3 (22).

The nuchal plate of Protostega differs widely from that of the living sea turtle, but in no point more widely than in the complete absence of the process on the under side for articulation with the last cervical. In Osteopygis, a sea turtle from the cretaceous, there is no trace of this process, but in Lytoloma, a form from the upper cretaceous and eocene, the eocene forms show the beginning of the process in a small tubercle (22).

The carapace of Protostega is now seen to be intermediate between the Dermochelyiidae and the Cheloniidae, with several primitive characters which are ancestral to both.

The vertebrae are represented by only two, from the caudal region. These are deeply concave in front, with the arch ossified with the centrum. The anterior zygapophyses extend well forward of the anterior edge of the centrum, and the top of the 
arch is broad and rugose. There is a triangular articular face at the base of the arch on the anterior portion of the centrum. The description of the vertebrae from Protostega given by Cope (32) is here quoted to show their general nature.

He says of the vertebrae: "These have been recognized chiefly by their neural arches, which are separate. They are in form something like an X, the extremities of the limbs carrying the zygapophysial surfaces. The only point of contact with the centrum is a wide process, which stands beneath the anterior zygapophyses, and spreads out foot-like obliquely forward and outward to beyond the line of the anterior margin. Its surface extends nowhere posterior to the surface of the zygapophysis above it, but a little farther inward. Its outer margin rises ridge-like to the under side of the neural arch, and each one, forming a semicircle, forms the boundary of the neural, and turning outward, forms the inner boundary of the posterior or down-looking zygapophysis. The space between these apophyses is roofed over so as to produce a shallow zygantrum, which, however, only seems to roof over the deep emargination of the neural arch of the vertebra immediately following. The anterior zygapophyses are often broken away, so that the neurapophysial supports look like the missing pair, when the difficulty ensues that both pairs look downward. The top of the neural arch is, in two cases, broad and flat; in two others there is an obtuse keel.

"The centra, apart from their arches, are puzzling bodies, especially since in the present case they are somewhat flattened by pressure. They differ materially in size, one of them being twice the size of the others. The smaller ones are of the balland-socket type, and have a deep longitudinal groove on each side. The thickened portion of the centrum forms the inferior boundary of the pit groove, while a thinner portion, possibly a diapophysis, limits it above. It is, however, thin, and has no great length. There is no sign of chevron bones and articulation, so that these vertebrae may have been cervical. Their bodies are, however, shorter and wider than in those vertebrae of any known tortoise. A groove on the upper surface represents the neural canal, while a flat area on each side in front 
supports the neuropophyses. The large centrum exhibits the superior groove and antero-lateral platform for support of the neural arch. One end is cupped obliquely, while the other is nearly plane, with the same obliquity and a slightly raised margin. Its outline is subtriangular. The lower side of this centrum possesses a short keel posteriorly. The sides exhibit no pit, but have a thin edge, which is concave behind the middle and then turned outward. I can see no articulation for a rib."

These vertebrae are stated by Cope to be most closely related to Dermochelys. Unfortunately, the material is too limited to admit any positive conclusions to be drawn as to the relationship of Protostega; but it is necessary here to note the close resemblance between the cervical vertebrae of Dermochelys and the Cheloniidae. Both have the strong articular process for the nuchal plate on the last cervical, and the articular faces between the 6 and 7 are plain.

Limbs. - The humerus is very broad and strong. The area for cartilaginous attachment on the mesial process is entirely separate from the area on the head, which is in turn separate from the radial process. In the smaller specimen the areas are all united. This is evidently a variation due to age, as the same thing is observable in large and small specimens of Chelonia mydas. The radial process lies near the center of the shaft, and is very prominent. It is simple, instead of having the $\mathrm{U}$ or V shape of the same process in existing sea turtles and in Psephophorus. The ento- and ecto-condyles and the entepicondylar and ectepicondylar processes are strong and prominent. The ectepicondylar foramen is quite large. The shaft of the bone was somewhat flattened and constricted beneath the head (PI. VI, Fig. I2).

\section{Measurements.}

Length from distal end to top of head . . . . . . . . .348 meters

Greatest width at distal end . . . . . . . . . . . . . 655 "

Length from exterior edge of head to end of mesial process .175 "

The humerus shows a somewhat close resemblance to that of Psephophorus and Dermochelys. The radial process is simple, stands higher on the shaft, and lacks the downward prolonga- 
tion shown in those forms. The higher position of the radial process is a primitive character, and is well shown in Lytoloma (33) and in Chelonia girundica (34), as figured by Delfortrie.

The radius and ulna are apparently represented by the proximal ends of two bones that from their size could not have belonged to the posterior extremity. They are so crushed as to afford no distinctive characters.

The scapulae show a broad angle between the scapula proper and the proscapular process. Both parts are strongly compressed, but show on their ends large areas for cartilaginous attachment. The neck of the glenoid portion is short in com. parison with existing members of the Cheloniidae. The proscapular process is much the shorter. The glenoid articular portion shows two faces: one for the coracoid and the other forming part of the glenoid cavity. The whole bone is very strongly built (Pl. VI, Fig. I3).

The coracoids are long, slender bones, greatly thickened proximally where they articulate with the scapulae. Distally the shaft becomes flattened and very thin. Upon the upper surface there is a strong ridge running from the proximal end out into the flattened part of the shaft, where it disappears. This ridge is present in both Chelonia and Dermochelys, but is absent in Thalassochelys. In the latter form the whole bone is proportionately shorter and stouter (P1. VI, Fig. I4).

Measurements.

Length of most nearly complete bone . . . .405 meters

Breadth distal end . . . . . . . . . . .075 “

The pubis has a very large and distally expanded ectopubis. It is much larger than the entopubis, and joins it at almost a right angle; in these respects it differs from the living sea turtles, where the two processes meet at an angle. The greatest axis of the ectopubis is in almost a line with the axis of the whole pubis. In the Pinnata these two meet at an angle. The entopubis joins the main body of the bone at almost a right angle by a very short and very broad neck, the anterior edge of which nearly reaches the edge of the acetabular face. The symphysial faces of the entoischia were nearly straight, 
so that they touched for a great part of their length. The process bearing the articular faces for the other bones of the pelvis is short and strong (PI. VI, Fig. 15).

\section{MEASUREMENTS.}

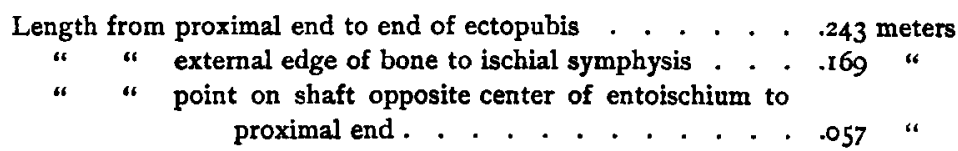

The ischium is somewhat hourglass-shaped in profile, with the distal end the largest and the middle of the bone much contracted. The broader portion of the shaft is thin, and the anterior edge rounded and thickened. The symphysial edge is somewhat convex, the two bones meeting probably in the middle portion only. The pubo-ischiatic foramen was small in Dermochelys (Pl. VI, Fig. I6).

The ilium is a short, strong bone, concave on its lower surface, and angularly convex above from before backwards. The distal articular surface is confined to the end of the bone. The center of the upper side is rugose for cartilaginous attachment (Pl. VI, Fig. 17). The figure of the ilium is made from the smaller specimen, as it is much more perfect than the larger.

The femur is much smaller and more slender than the humerus. The distal end is expanded. The shaft is contracted below the head, which was supported on a well-developed neck (Pl. VI, Fig. I8).

\section{Measurements.}

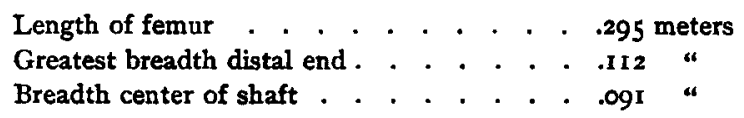

Protostega has, then, the following points in common with the Cheloniidae: the peripherals, the condition of the plastron (part.), the lack of such a large amount of intercalated cartilage in the articulations of the bones of the skull, the nature of the semicircular canals in the paroccipital, petrosal, and exoccipital, and the shape of these bones; the formation of the foramen for the external carotid by the petrosal and quadrate to the almost complete exclusion of the paroccipital, the form and position of 
the quadrate, the form of the squamosal and its close articulation with the quadrate, the articulation of the paroccipital with the squamosal, the well-ossified and separated condylar portions of the exoccipital and basioccipital, the manner of articulation of the palatines with the maxillaries, the posterior nares (part.), and the form of the mandible.

With Dermochelys it agrees in the broad basioccipital with its lateral processes preventing the articulation of the pterygoid and exoccipital, the broad basisphenoid separating the pterygoids on the base of the skull (to a less extent than in Dermochelys), the nonappearance of the pterygoids on the posterior aspect of the skull and their not being perforated by a branch of the carotid artery, the large groove on the pterygoid for the epipterygoid process of the quadrate, the large epipterygoid process of the quadrate, the posterior nares (part.), and the vomer, the lack of a carapace, the large nuchal, the humerus (part.), and the plastron (part.). There should also be mentioned here the stapes, which is even larger than in Dermochelys.

Points separating Protostega from both forms are the lack of dermal ossifications on the back, the manner of articulation of the pterygoid and quadrate, the presence of a presplenial bone in the jaw, the lack of any articular process on the under side of the nuchal, the simple radial process of the humerus, and the peculiar bent form of the xiphiplastra.

Protostega is distinctly an intermediate form.

In the paper containing the description of Protostega (2) Cope attempted a restoration from the material at his command. $\mathrm{He}$ estimated the head as $24 \frac{5}{8}$ inches long, and by assuming the proportions to be near those of Chelonia, the neck and carapace as $138 \frac{2}{8}$ inches, making a total length of $154 \frac{7}{8}$ inches, or I 2.83 feet. (He evidently deducted 8 inches from the neck as remaining within the carapace.) From the ribs and vertebrae he estimated the width of the carapace to be $36 \frac{1}{2}$ inches, and the length 118 inches. The series of marginals did not justify this length, but he considered that they were not united, and that the intervening spaces would make up the deficiency. His final conclusion was that the carapace was more elongate and narrower than in any existing form of sea turtle. 
In a recent paper (43), Dr. O. P. Hay has described portions of the plastron of a large specimen of Protostega, and attempted a restoration. The materials on which his restoration was based were the almost complete hyo- and hypo-plastra of one side and a fragmentary nuchal. Regarding the plastron he says (p. 58): "In Thalassochelys the anterior end of the epiplastra extends in front of a line joining the bottoms of the excavations for the fore limbs a distance equal to that from the bottom of the excavations for the fore limbs to those of the hind limbs. This, in the Protostega plastron before me, amounts to $84 \mathrm{~cm}$. The xiphiplastra of Thalassochelys extends behind the excavations for the hinder limbs as far as do the epiplastra from the anterior excavations. If these proportions hold good for Protostega, the whole length of the plastron would amount to at least 2.4 meters"; and further (p. 59): " had the breadth of the body of Protostega possessed the same ratio to the length that we find in Thalassochely's, the lower side of the animal would have been about 2.2 meters wide." In regard to the fontanelle: "if we have placed the plastral bones aright, there is left between them a great fontanelle. Where the hypoplastra are widest, this is about $43 \mathrm{~cm}$. in width, and opposite the union of the hyo- and hypo-plastron about $90 \mathrm{~cm}$. This is somewhat smaller, however, than the fontanelle found in Protosphargis, and much smaller than that of Dermochelys." The head he estimates as $32 \mathrm{~cm}$., from the snout to the end of the occipital condyle, and concludes as follows (p. 62): "The length of the carapace of Chelonia has a ratio to the plastron of about $3 \mathrm{I}$ to 24. Hence the length of the carapace of my specimen must have been close to 3.1 meters. The neck of our living marine turtles projects beyond the front of the carapace a distance equal to at least $\frac{1}{6}$ of the length of the carapace. Hence we are safe in allowing $50 \mathrm{~cm}$. for the neck outside of the shell. We have, therefore, for the length of this turtle the following figures:

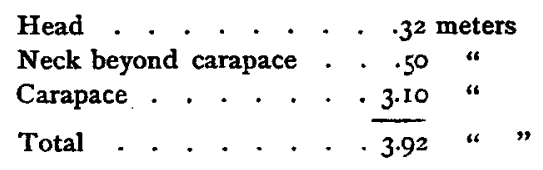


The specimens just described afford material for quite accurate measurements, which give results different from those obtained by Cope and Hay, the main discrepancy being in the relative length of the carapace to its breadth. The present specimen shows the peculiar bent condition of the xiphiplastra, which was not indicated in the specimens described by the authors mentioned. This would account for a considerable reduction of the length of the plastron, and a still further reduction is quite certainly to be found in the condition of the epiplastra. In none of the known specimens has any trace of epiplastra been discovered, and neither in the specimen here described nor in Dr. Hay's specimen can I find any trace of attachment of the epiplastra. Moreover, the anterior ends of the hyoplastra meet over the anterior end of the fontanelle. In the plate of Protosphargis given by Capellini the restored epiplastra extend beyond the exterior end of the hyoplastra a distance of one-tenth the length of the plastron as restored. This restoration is open to doubt, however, as the close resemblance of Protosphargis to Protostega makes it possible that the distal ends of the xiphiplastra were incurved as in Protostega. Only the proximal ends of both epiplastra and xiphiplastra are known. It may be assumed, however, for the purposes of this restoration, that the epiplastra extended in front of the hyoplastra a distance of one-tenth the length of the plastron.

The distance from the posterior edge of the conjoined xiphiplastra to the anterior extent of the hyoplastra is I.I 5 meters; adding to this one-tenth the length of the plastron, we have 1.27 meters, instead of 2.4 meters, as estimated by Hay.

Fortunately, in the process of fossilization, the nuchal plate was pressed down upon the plates below, preserving them in their normal position, and rendering it possible to give exact measurements of the fontanelle. It was bridged in its anterior and posterior extent by the processes from the plastral plates, and at its widest part measured .525 meters, instead of .90 , as estimated by Hay.

If we assume the ratio of the carapace to the plastron as $3 \mathbf{I}$ to 24, as in Chelonia, the carapace was 1.64 meters long. In a three-fourths grown specimen of Chelonia the ratio of the 
breadth of the plastron to the breadth of the lower surface of the turtle is as 5 to 6 . The distance across the plastron in this specimen of Protostega in its widest place is 1.029 meters; and this, according to the ratio stated, would make the lower surface of the turtle 1.235 meters wide. The widest part of the carapace in Chelonia does not correspond with the widest part of the plastron, but is broader somewhat behind it, so the general form of the carapace was not long and narrow, but almost round.

As shown in Pl. V, Fig. 6, the quadrate, pterygoid, and palatine of the smaller specimen are all united and very slightly distorted by pressure, especially in a linear direction. The measurements of these bones, including length of quadrate, length of condylar face of quadrate, and length from posterior end of quadrate to anterior end of palatine, are almost exactly the same as that of a skull of Chelonia mydas, which measures . 197 meters from snout to occipital condyle. The humerus of the smaller specimen is six-elevenths as large as the same bone in the larger specimen, both being in excellent condition. If it is assumed that the same ratio applies to the head, the larger specimen would have a skull measuring .363 meters from snout to occipital condyle.

No material is at hand to give exact measurements of the neck, but assuming with Hay that the neck extended in front of the carapace a distance equal to one-sixth of the carapace, it would have a length of .278 meters.

The exact figures are:

Plastron, from xiphiplastra to anterior end, hyoplastra . . . 1.15 meters

Breadth of fontanelle at suture between hyo- and hypo-plastra . .525 “

Breadth of plastron at widest part of hyoplastra . . . . . . 1.029 “

The estimated figures are:

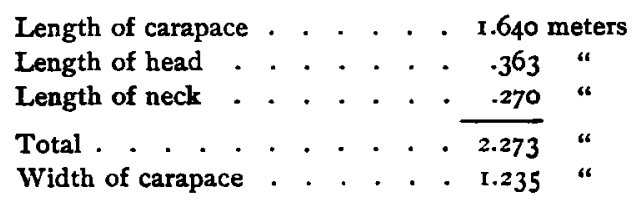

In both Cope's and Hay's specimens the animal was a very little larger than in the present one. 
Systematic Relationship of Protostega and Allied Forms.

The forms most important in this connection are:

Dermochelyidae.

Dermochelys Blnv. (35).

Psephophorus v. Meyer (36).

Eosphargis Lydekker (30).

Protostegidae (3).

Protostega Cope (2).

Protosphargis Cap. (3I).

(?) Pseudosphargis Dames (28).

Cheloniidae.

Osteopygis Cope (37).

Allopleuron Baur (20).

Lytoloma Cope (38).

And also the living forms of the Cheloniidae.

The known material is deficient in comparable portions, thus only a part of a head and nothing of the body is known of Pseudosphargis, while the skull is absent and the body very perfectly preserved in Protosphargis. Eosphargis is known from the skull and very incomplete body skeleton, and so on. Conclusions drawn from such material must be, in a sense provisional and await the evidence of future discoveries for confirmation.

The Protostegidae are characterized as a distinct group by the presence of descending parietal plates and the absence of a carapace. In the middle cretaceous form, Protostega, the descending parietal plates are well developed. In the upper cretaceous form, Protosphargis, as already stated, the skull is unknown, but the almost generic identity of the body skeleton with Protostega makes the presence of the plates very probable. In Pseudosphargis of the oligocene they are present, but the lower end has only a weak connection with the pterygoid; of this form, Dames says (28), p. I7, “ Bei Pseudosphargis endlich bilden sie im oberen Theil noch wohlentwickelte Lamellen, die jedoch mit inrem Vorderrande weit hinter der erwähnten Verbindungslinie der Orbitae zurückbleiben, im untern Theile sind sie auf schwache Pfeiler reducirt, deren gänzliches Verschwinden eine sphargis- 
ähnliche Ausbildung ergeben würde." It is placed among the Protostegidae upon the evidence of the descending processes; but, as will be shown later, the flat, wide skull has a strong resemblance to some of the Dermochelyidae.

No forms of this family have shown the presence of dermal ossifications in the carapace, but all, in which the carapace is known, do have peripherals which are unknown by observation in the Dermochelyidae.

The nuchal plate of the middle cretaceous form, Osteopygis, is known to lack the process on the under side for the last cervical vertebra. The other forms, probably, were devoid of the process.

The Dermochelyidae have a carapace formed of dermal ossifications, no peripherals, and an entire lack of the descending plates of the parietals. The earliest known form, Eosphargis, from the eocene, has the carapace represented by a median row of scutes which are, possibly, the loosened and expanded neural plates; the peripherals were supposed to have been present by Lydekker (30). The skull shows no trace of the parietal plates, and is broad and flat.

The next form, Psephophorus, ranges from the eocene into the miocene. It has the tesselated dermal ossifications of the carapace already well developed, no peripherals, and the humerus very similar to that of Dermochelys.

The Cheloniidae afford better material for comparison. The earliest form, Osteopygis, from the middle cretaceous, had eleven peripherals, 2, and II were free from rib attachment, 2 and 8 had deep pits for attachment to the plastron. Between these there was a small fontanelle. The carapace was practically closed. Allopleuron (Chelone Hoffmani Gray) of the upper cretaceous presents an evident offshoot from the true line of the Cheloniidae. The carapace was long and narrow, the nuchal deeply emarginate, and the neurals short and wide with a long keel. The pleurals are of considerable antero-posterior extent, but are confined to the proximal ends of the ribs, which are very slender. The nuchal shows no process on its under side. The peripherals are long and slender. The posterior nares are located far back. 
Lytoloma of the upper cretaceous and lower eocene has eleven peripherals; 1,2 , and 10 are free, the third has a small pit for a process from the plastron. According to Baur (22), the specimens in the Bruxelles Museum have no pit. The nares and orbits are directed upward. The palatal aspects of the temporal fossae are wider than long. The ecto-pterygoid process is near the anterior extremity of the pterygoid. The posterior nares are in the hinder half of the cranium. The vacuities of the shell are even less than in the recent Thalassochelys. The nuchal in the eocene form has the beginning of a process for the cervical.

Argillochelys from the eocene has the orbits and nares directed slightly upward. The palatal apertures of the temporal fossae are as wide as long. The ecto-pterygoid process is at the antero-external angle. The posterior nares are in the anterior half of the cranium. The carapace was, probably, very close to that of Thalassochelys.

Thalassochelys, eocene and recent, has more than I I peripherals, the addition taking place between the $I$ and 3. I, 2, and 9 are free from ribs; there are no pits for the plastron. The carapace is completely ossified in the adult. The posterior nares are in the middle half of the skull, retreating as age advances. The nuchal has a process for the cervical vertebrae.

Before attempting to interpret the facts just given, it may be of value to review briefly the discussion between Baur, Dollo, and Boulenger on the systematic position of Dermochelys, and the validity of the group Athecae.

Baur in 1886 (19) declared that the separation of Dermochelys from the rest of the Testudines was a purely artificial one: "Diese Absonderung der Dermatochelyidae ist keine natürliche sondern eine absolut künstliche," giving as his reasons:

I. That the configuration of the skull and of its separate elements is directly comparable to that of the Cheloniidae, and especially to Eretmochelys.

2. The cervical vertebrae are like those of the Cheloniidae, the fourth being biconvex.

3. The nature of the claws. In Thalassochelys the first and 
second digits have claws; in Eretmochelys the first and sometimes the second; and in Dermochelys there are no claws.

4. The plastron of Dermochelys is reduced, not primitive. In the cretaceous Protostega and Protosphargis the plastron is much more strongly developed than in Dermochelys. These forms also lack the entoplastron, which is present in the Cheloniidae. The remaining elements of the plastron are directly referable to that of the Cheloniidae, though the hyo- and hypoplastron are not united by suture.

5. In addition to the mosaic-like carapace of Dermochelys there is present a nuchal plate which is comparable to that of the Cheloniidae and to it alone.

His conclusion was that the only difference between the Athecae and Thecophora is in the form of the carapace and its complete separation from the inner skeleton, that the ancestors of the Athecae had the carapace united with the inner skeleton, and that the peculiar carapace was formed by the breaking up into small pieces of the original carapace; giving as evidence of this process the case of a specimen of Eretmochelys, in which he observed that the costal plates from the third to the sixth had separate ossicles of bone on their edges. He also cited the reduction of the peripherals of Eretmochelys and their complete disappearance in Dermochelys, and the peculiar anterior rib in both forms.

To this paper Dollo (9 and 10) replied in detail, maintaining the natural value of the group Athecae.

I. He considered that if Dermochelys was descended from the Cheloniidae, in which there are always fontanelles in the carapace, that there should be some in the carapace of Dermochelys. He regarded a supposition that such fontanelles existed, but had been filled up by the dermal ossifications as improbable. He says (9), p. I65, "Or préfère-t-on supposer que les ancêtres des Chélonées avaient une carapace sans fontanelles et que, de cette souche, se seraient dévélloppés par delamination, les Athèques, et, par formation de fontanelles, les Chélonées actuelles ?"; however, he considered this as improbable, as both the embryological evidence of living forms and the paleontological evidence of the earliest known turtle (Thalassemys 
Rutimeyer) is in favor of the presence of fontanelles in the carapace.

He found difficulty in explaining, on Dr. Baur's hypothesis, how the plastral bones could still be present in Dermochelys, and separate from the external layer of dermal ossifications. $\mathrm{He}$ considered the dermal ossifications of Ostracion, Polacanthus, and Glyptodon to be of the same origin as those in Dermochelys and that no one would imagine that they came from the ribs.

He saw no relation between the bones of the skull in the two families. The shape of the pterygoids and the posterior nares located far forward militated against the idea of aquatic adaptation.

He showed that the series formed by Baur on the possession of claws was inaccurate, that Eretmochelys had two claws, and that the genus was formed for the reception of forms with two claws.

He regarded the plastron of Dermochelys as likely to be as much primitive as reduced.

The nuchal plate might be a more ancient form than the other peripherals, and have its origin in the necessity for a strong attachment for the neck muscles.

The articular faces of the cervical vertebrae he considered to be too variable to afford safe evidence of affinity.

He questioned the presence of peripherals in Protostega, and supposed that the peculiarity of the anterior rib was not necessarily related to the possession of the carapace, but might have been derived from ancestral forms.

In the same year as Dollo's latest paper appeared one by Boulenger (13), in which he said: "For my part I have to say that the statement that Dermochelys differs from the Cheloniidae only in the configuration and isolation of the carapace is simply monstrous. ...

" $\mathrm{He}$ [Dr. Baur] actually states the head and limbs are fundamentally the same in Dermochelys and in the Cheloniidae. The skull of the former bears a general resemblance to that of the true turtles; but this is limited to the shape, and, to a certain extent, the general constitution of the temporal roof; in the absence of the column-like processes of the parietals, descend- 
ing to the pterygoids in front of the supraoccipital and the prootics, it differs from that of all other Chelonians. Thus, in addition to the shape of the humerus and the proportions of the phalanges, the fore limb differs in the radius and ulna being subequal in length and placed side by side in a horizontal plane, and in the fifth metacarpal, instead of the first, being the shortest."

In 1889 appeared Baur's reply to these papers (23). Taking up Dollo's objections first, he stated the belief that the fontanelles in the carapace of Dermochelys might be filled up by the expansion of the elements of the dermal carapace, after they had lost connection with the inner skeleton, citing as an example of such disappearance of the fontanelles the case of an old specimen of Aspidonectes (Amyda) muticus.

He showed that the oldest known specimen of turtles was not Thalassemys Rütimeyer, with fontanelles, but Proganochelys Quenstedtii Baur, which had no fontanelles; also, that in some of the living sea turtles the carapace becomes closed in old age (Colpochelys and Thalassochelys). He showed that the direct ancestors of the sea turtles had no fontanelles in the carapace, and that the plastron was stronger than in recent forms. To the objection that the embryonic forms showed fontanelles in the carapace he replied that the principles of embryology could not be used in interpreting the meaning of the ontogenetic development of dermal ossifications.

He applied the statement that the ontogenetic development of the exoskeleton was of slight morphological value to the statement by Dollo that if Baur's hypothesis was a true one, the embryo should show simple ribs becoming confluent, and again single, and also to the objection that the dermal ossifications overlay the plastral elements from which they were supposed to take origin.

He showed that the posterior nares were the same in Dermochelys as in the Cheloniidae, that the nature of the articular faces of the cervical vertebrae was constant, and that the plastron of Dermochelys was reduced from a stronger form. $\mathrm{He}$ reëstablished his series based on the claws as follows: "Bei Caretta (Eretmochelys) sind gewöhnlich 2 Klauen vorhanden 
ebenso bei Thalassochelys, dass aber bei Chelonia, Lepidochelys, und Colpochelys im allgemeinen nur eine Klaue vorkommt. Dermochelys besitzt gar keine."

He showed that the presence of peripherals in Protostega and Protosphargis was no longer to be questioned.

In reply to Boulenger's paper he brought forward additional evidence of the relationship between Dermochelys and the Cheloniidae. He concludes (p. 190): "Ich habe früher [Science, 1888] die Vermutung ausgesprochen dass Dermochelys von einer Form der Pinnata mit volkommenem Rücken- und Bauchschild abstamme, während ich annahm, dass Protostega und Protosphargis von den Cheloniidae durch Vermittlung von Allopleuron (Chelonia Hoffmani) sich entwickelt haben. Es scheint mir jedoch wahrscheinlicher, dass Dermochelys und Psephophorus direkt auf Protostega- oder Protosphargis-ähnliche Formen zurückführbar sind, und dass der mosaikartige Panzer möglicherweise eine Neubildung darstellt." Again: " Darüber aber ist kein Zweifel, dass Dermochelys und Psephophorus keine ursprünglichen Formen sind, sondern dass sie von wahren 'Thecophoren ' und zwar von den 'Pinnaten' abstammen, um mich hier dieses Ausdrucks zu bedienen."

Dr. Baur has since expressed his belief that the carapace of Dermochelys was not formed, as he formerly supposed, by the breaking up of the plates of the original carapace, but by a secondary ossification of the integument after the neurals and costals had disappeared, the state observed in Protostega and Protosphargis.

The matter stood thus unsettled before the present specimens were known. They clearly show Protostega to be an intermediate form; but was it a step in a series advancing from Dermochelys to the Cheloniidae, or a specialization of the primitive Cheloniidae toward Dermochelys? I believe the latter.

There can no longer remain a doubt as to the possibility of referring the skull of Dermochelys to that of the Cheloniidae; Protostega fills the gap completely. The lost neurals and costals of Dermochelys are seen in the expanded ribs of Protostega, and the vanished peripherals are strong in the cretaceous genus. The lack of a process on the nuchal of Protostega speaks strongly for the origin of Dermochelys by specialization 
from the stem of the Cheloniidae. Is it likely that the primitive form would have this process, lose it in the cretaceous, and regain it in the upper eocene and later forms? It is more likely that the Dermochelyidae arose after the process had appeared in the main stem, and the Protostegidae before it. Nor is it likely that the process is secondary in either of the families possessing it. In the cases where such parts are seemingly reproduced in nature, it is generally found that some neighboring part has assumed the function and appearance of the lost part; there is nothing here that could have done this.

Allopleuron connects Protostega with the main stem of the Cheloniidae; it cannot be in the direct line, as it is upper cretaceous, while Protostega is middle cretaceous; but its immediate ancestor must have been the connecting form. As shown in the description given above, and as will be more readily seen by reference to the plates in M. Ubagh's two papers $(41,42)$, the skull is closely related to that of Thalassochelys, while the slender ribs and reduced pleurals are a direct step toward the state found in Protostega (see Pls. I, VII, XII, and XIII of Winkler's monograph, 40).

The point of approach of Protostega to the stem is indicated by the lacking process on the nuchal. In Osteopygis, the cretaceous form, the process is wanting, while in Lytoloma of the upper cretaceous and in the form of the lower eocene it is present. Evidently Protostega branched off before the time of Lytoloma.

Protosphargis of the upper cretaceous is the next step in the Protostegidae, as evidenced by its appearance in time, its simpler ribs, and reduced peripherals and plastron.

Pseudosphargis is placed as the last of the known Protostegidae because of the presence of the descending parietal plates and its appearance in the oligocene. The lack of any portion of the animal beyond the posterior part of the skull makes the determination of its systematic position doubtful. If it should prove to have a process on the nuchal plate for the eight cervical vertebrae and any trace of a dermal carapace, it might, though occurring so late, be regarded as representing the first step toward Eosphargis. This view would be supported by the weak attachment of the lower end of the parietal plates. 
In a slightly different direction developed those forms with the parietal plates absent, and dermal ossifications in the carapace and plastron culminating in Dermochelys. The first form to appear was Eosphargis, slightly off the main line of the Dermochelys branch. The primitive form with parietal plates and lacking dermal ossifications has yet to be found to connect the branch with the main stem. From the strong resemblance of Eosphargis to Dermochelys it is fair to say that it had a process on the nuchal plate, and if so it must have come from a form which left the main stem after Lytoloma had developed the nuchal process. That it is slightly different from the rest of the branch is shown by the peculiar dermal carapace, consisting of the large carinated dermal scutes, instead of the small ones of Psephophorus and Dermochelys. It may be that these scutes are the last of the neurals; if so it represents a stage in its branch corresponding to a stage between Allopleuron and Protostega in the other branch.

The second member of this branch is Psephophorus, running from the eocene to the pliocene; it has been shown by Dollo to be unquestionably a member of the Dermochelyidae, with well-developed dermal ossifications in the carapace, complete loss of neurals and peripherals, and a characteristic humerus.

Dermochelys is the culminating form of this branch. The series Osteopygis, Lytoloma, Argillochelys, Thalassochelys, representing stages in the main line of the Cheloniidae, needs no further explanation than the facts set forth above.

The ideas here expressed may best be seen by reference to the following diagram:

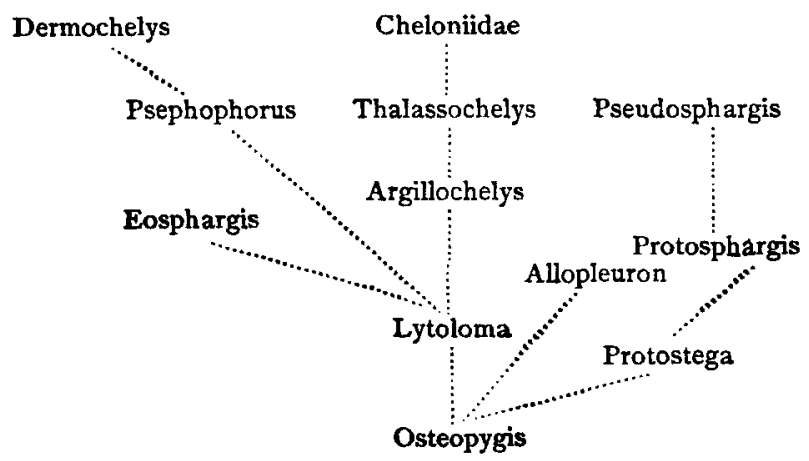


We may then conclude that Protostega is a connecting link between Dermochelys and the Chelonizdae. The evidence for this position of Dermochelys may be stated as follows:

(I) The bones of the head are referable to those in the head of the Cheloniidae. The intermediate form is represented in Protostega.

(2) The cervical vertebrae are alike in both families. The fourth is biconvex and the articular surfaces between the sixth and seventh are flat.

(3) The plastron of Dermochelys is a reduced form of the plastron of the early Cheloniidae. The intermediate stages are represented in Protostega and Protosphargis.

(4) The carapace is composed of dermal ossifications; they appeared after the bony carapace had disappeared by ossifica. tion of the integument. The original carapace was removed by the enlargement of its lateral fontanelles. An intermediate form, with the carapace gone and the separate ossifications not yet formed, is represented in Protostega and Protosphargis.

(5) The process of the disappearance of the peripherals is known in all stages.

(6) The nuchal plate of Dermochelys is provided with a process for articulation with the last cervical; this process is absent in Protostega and present in the Cheloniidae. The plan of development could not have included, in the time occupied, its loss and subsequent reacquisition. The line of Dermochelys rather took origin after the process was developed in the main stem of the Cheloniidae.

In conclusion I wish to express my thanks to Dr. G. Baur and to Dr. S. W. Williston for material most kindly furnished me for these studies.

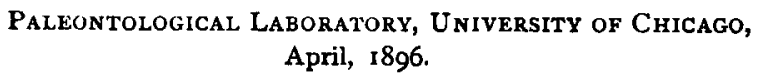

Additional Note.

Since the above was written Mr. G. R. Wieland has described the remains of a large sea turtle from the upper cretaceous of 
South Dakota. ${ }^{1}$ The description includes the carapace, vertebrae, limb bones, and pectoral girdle, which he regards as indicating a new genus and species, Archelon ischyros. Nothing is added to our knowledge of the morphology of the extinct sea turtles, except the presence of a row of neural plates. This point shows my conclusions as to their absence to have been an error.

Mr. Wieland bases his new. genus largely on the disparity in size between it and Cope's specimens of Protostega, and on several minor differences in the vertebrae, scapulae, and coracoids. The difference in size between two forms can rarely be used as a criterion for determining their generic individuality. For one accustomed to the great range of this feature in the fossil reptilia, and the persistent, though slow, growth throughout life of many recent forms, the use of this character seems attended with grave danger. The present paper was founded on two specimens of Protostega, one about half the size of the other, while Cope's described specimen is intermediate in size. The "minor development of the smaller trochanter" attributed to Archelon (p. 406), and the presence of "longitudinal depressions" on the shaft of the proscapular process of the scapula (procoracoscapular), instead of a " rotund" outer edge (p. 404), are, with characters of a like nature, features which might be readily produced or destroyed by the compression from which all specimens from the Kansas chalk suffer.

Mr. Wieland further speaks of the greater breadth of the carapace of Archelon as compared with Protostega. His conclusions are based on the calculations of Cope and Hay which I have shown above to be erroneous. His specimen has a length of 3.52 meters, and a breadth of 2.25 , a little less than two-thirds, while mine is a little over one-half as wide as long. Archelon must be considered as a synonym of Protostega, and even its specific separation remain an open question.

December I 4, 1896.

1 Archelon ischyros: a New Gigantic Cryptodire Testudinate from the Fort Pierre Cretaceous of South Dakota. Am. Jour. Sci., vol. ii, December, I896, p. 399, I Pl. 


\section{BIBLIOGRAPHY.}

1. Cope, E. D. On the Homologies of some of the Cranial Bones of Reptilia and on the Systematic Arrangement of the Class. Proc. Am. Ass. Adv. Sci., vol. xix, p. 235 . 1871.

2. Cope, E. D. A Description of the Genus Protostega, a Form of Extinct Testudinata. Proc. Am. Phil. Soc. Philadelphia, vol. xii, p. $422 . \quad 1872$.

3. COPE, E. D. Check List of North American Batrachia and Reptilia. Bull. U. S. Nat. Mus. Washington, no. I, p. 16.1875.

4. COPE, E. D. On the Phylogeny of Genera of Testudinata. Sixth Ann. Report, U. S. G. S., Hayden, p. 649. Washington, 1873.

5. Gervais, Paul. Ostéologie du Sphargis Luth (Sphargis coriacea). Nouvelles Archives du Musém, tome vii. Paris, 1872.

6. Seeley, H. G. On Psephophorus polygonus. Quart. Journ. Geol. Soc., vol. xxxvi, p. 412. I 880 .

7. Döderlein, Ludwig. Elemente der Paläontologie. Steinman and Döderlein. Leipzig, r 880 .

8. Dollo, L. Première note sur les Chéloniens du Bruxellien (Éocène moyen) de la Belgique. Bull. Mus. Roy. Hist. Nat. de Belge, tome iv, p. 79. 1886 .

9. Dollo, L. Psephophorus. Annales de la Soc. Sci. de Bruxelles, I I année, p. 139.1887.

10. Dollo, L. Première note sur les Chéloniens Oligocènes et Néogènes de la Belgique. Bull. Mus. Roy. Hist. Nat. Belge, tome v, p. 59. 1888.

11. COPE, E. D. Syllabus of Lectures on Geology and Paleontology. Philadelphia, I 89I.

12. Smith-Woodward, A. On "Leathery Turtles," Recent and Fossil, and their Occurrence in British Eocene Deposits. Proc. Geol. Ass., vol. $x$, no. I, p. $5 . \quad 1887$.

13. Boulenger, G. A. Remarks on a Note by Dr. G. Baur on the Pleurodiran Chelonians. Ann. and Mag. Nat. Hist. Oct., 1888.

14. Boulenger and Günther. Article in Encyclopaedia Britannica, vol. xxiii; and Boulenger. Catalogue of Chelonians. 1889.

15. LYDEKKER, R. Nature, vol. lx, no. I, p. 6.1889.

I6. LyDekKer, R. Catalogue of the Fossil Reptilia and Amphibia of the British Museum, part iii. 1889.

17. Rütrmeyer, L. Die Fossilen Schildkröten von Solothurn und der übrigen Jura-formation. Neue Denkschriften der allgemeinen Schweizerischen Gesellschaft für die ges. Naturw., Bd. xxv. Zürich, I873.

18. Bernard, Felix. Paléontologie. Paris, 1895. 
I9. BaUR, G. Osteologische Notizen über Reptilien. Zoolog. Anzeig., no. 238. Nov. 22, 1886.

20. Baur, G. Unusual Dermal Ossifications. Science, xi, no. 268, p. 144. March 23, 1888 .

2I. BaUR, G. Osteolog. Not. Zoolog. Anzeig., no. 285. 1888.

22. BAUR, G. Osteolog. Not. Zoolog. Anzeig., no. 298. 1889.

23. BAUR, G. Die systematische Stellung von Dermochelys Blnv. Biolog. Centralblatt, Bd. ix, nos. 5, 6. Mai I und 15, 1889.

24. BAUR, G. Nachträgliche Bemerkungen über die systematische Stellung von Dermochelys Blnv., Bd: ix, nos. 20, 21. Dec., 1889.

25. Baur, G. On the Classification of the Testudinata. Am. Nat., p. 530. June, I89o.

26. Baur, G. Notes on the Classification of the Cryptodira. Am. Nat. July, I893.

27. Zitrel, Carl von. Handbuch der Palaeontologie, p. 517. I889.

28. Dames, W. Die Chelonier der Norddeutschen Tertiärformation. Palaeontolog. Abhandlungen Herausgegeben von Dames und Kayser, Neue Folge, Bd. ii, Heft 4.

29. BötTGER. Zoolog. Centralblatt, erster Jahrg., nos. 21-25. Jan., I 895.

30. LydekKer, R. On the Remains of Eocene and Mesozoic Chelonia and a Tooth of (?) Ornithopsis. Quart. Journ. Geol. Soc. May, 1889, p. 241.

31. Capellini, Giovanni. Il Chelonio Veronese (Protosphargis veronensis Cap.) scoperto nel 1852 nel cretaceo superiore presso Sant' Anna di Alfaedo in Valpolicella. Reale Academia dei Lincei (Anno ccloxxi, 1883-1884). Roma, 1884. 36 p., 7 pl.

32. CoPE, E. D. Report of the U.S. G.S. of the Territories, Hayden, 1876. Vol. ii, Cretaceous Vertebrata.

33. Dollo, L. On the Humerus of Euclastes. Geol. Mag., vol. v, no. 6. Dec. 3, 1888 .

34. Delfortrie, M.E. Les Chéloniens du Miocène Supérieur de la Gironde. Actes de la Societe . Linnéene de Bordeaux, tome xxvii, $4^{\mathrm{e}}$ livre. 1870 .

35. De Blainville. Bull. des Sciences par la Sociéte philomatique de Paris, année 1816 , p. I 19.

36. Meyer, H. v. Neues Jahrbuch für Mineralogie, Geognosie, Geologie und Petrefactenkunde. K. C. Leonhard und H. G. Bronn, 1847, p. 579.

37. Cope, E. D. Proc. Acad. Nat. Sci. Phil., p. 147. 1868.

38. Cope, E. D. Trans. Am. Phil. Soc., vol. xiv, part i, p. 144. 1870.

39. Fitzinger. Annal. Mus. Wien, vol. i, p. 121. 1835.

40. Winkrer, T. C. Les Tortues fossiles conservées dans le Musée Teyler et dans quelques autres Musées. Harlem, 1869.

41. Ubaghs, C. La Machoire de la Chelonia Hoffmani Gray. Annales Soc. de Belge, tome x, Pp. 25-35, P1. I. 
42. Ubaghs, C. Le Crane de la Chelone Hoffmani. Bull. de la Societé Belge de Géologie, de Paleontologie et d'Hydrologie, tome ii. Bruxelles, I 888. pp. 383-392, Pl. X-XII.

43. Hay, O. P. On Certain Portions of the Skeleton of Protostega gigas. Field Columbian Museum Publications, Zoölogical Series, vol. i, no. 2. Chicago, 1895.

44. Baur, G. Ueber die Morphologie des Unterkiefers der Reptilien. Anatomischer Anzeiger, Bd. xi, no. 13. 1895. 
CASE.

EXPLANATION OF PLATE IV.

Photograph of plastron with nuchal plate and peripherals. 


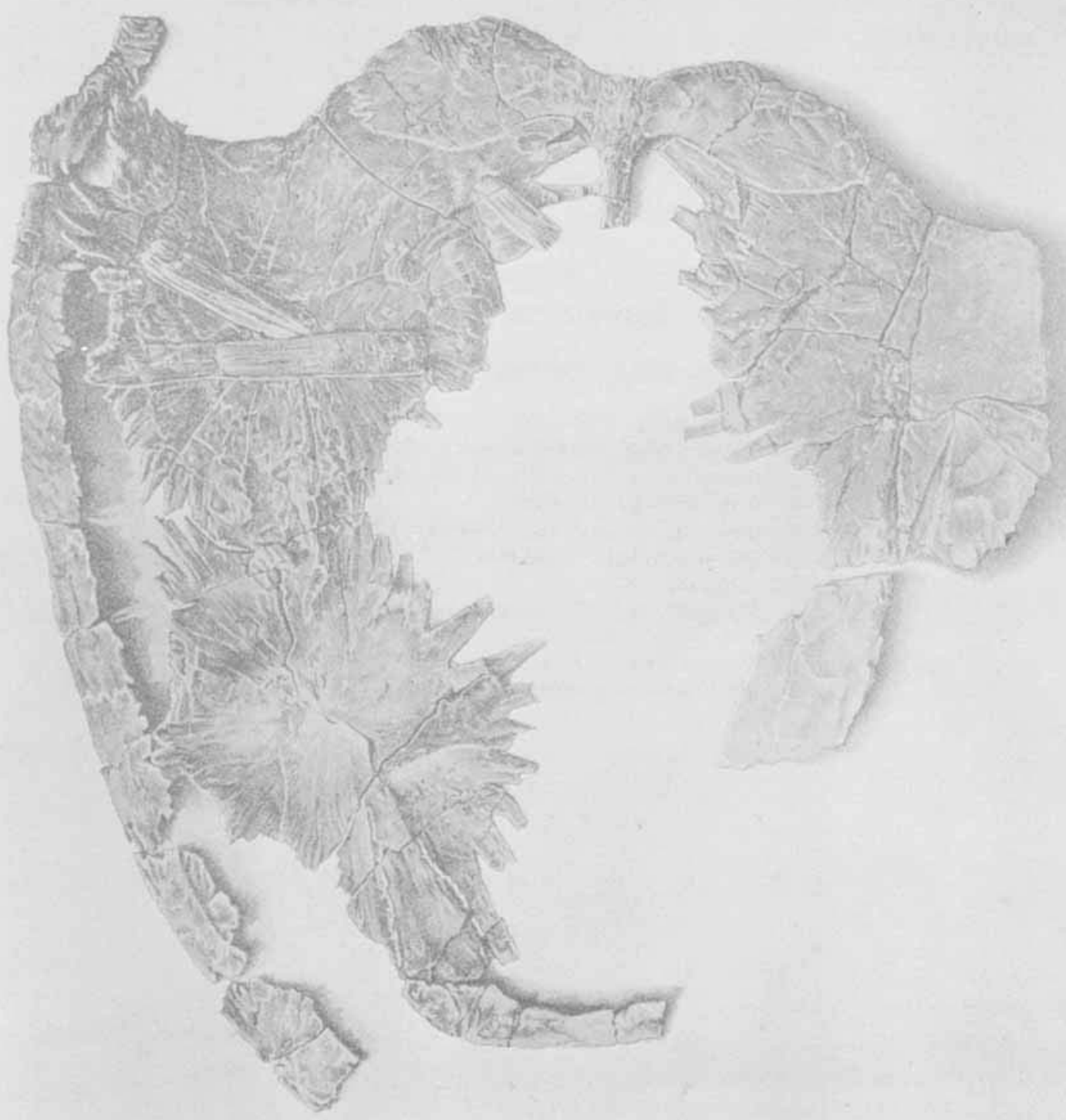




\section{EXPLANATION OF PLATE $v$.}

FIG. I. Supraoccipital \&. The badly crushed petrosal and paroccipital are not shown.

FIG. 2. Exoccipital t. Right side.

Fig. 3. Basioccipital 1. a, from above ; $b$, from below.

Fig. 4. Petrosal $\frac{t}{2}$. $a$, from within ; $b$, from without.

Fig. 5. Paroccipital t. Right side.

Fig. 6. Quadrate, pterygoid, and palatine $\frac{1}{2}$. Right side.

FIG. 7. Quadrate-jugal t. Right side.

FiG. 8. Lower jaw.

FIG. 9. Xiphiplastron $\mathrm{z}$. Left side, showing attachment with hypoplastron and xiphiplastron of right side.

FIG. Io. Nuchal plate a little over $\frac{1}{3}$.

FIG. II. Fifth and sixth peripherals. Left side. 


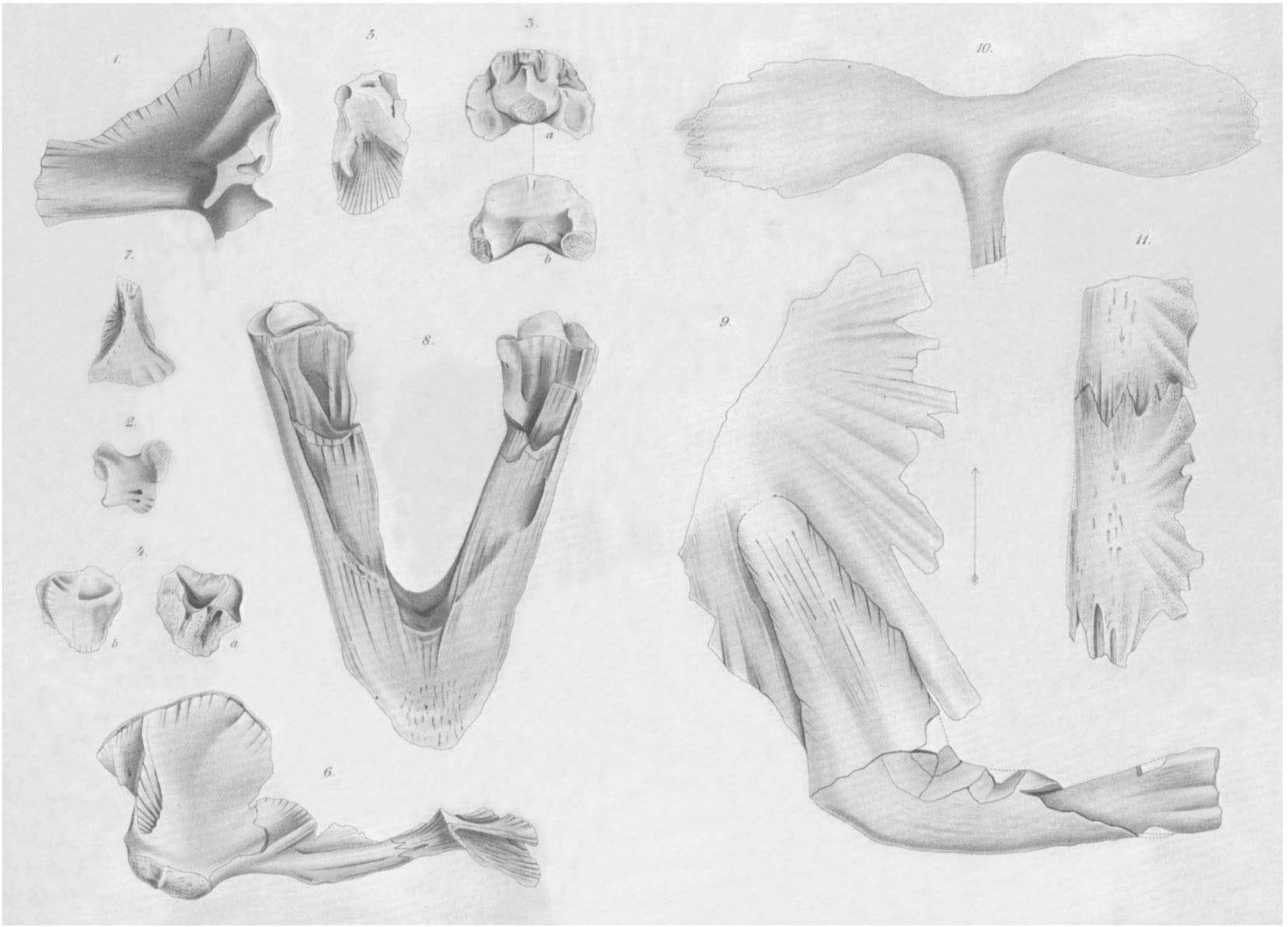




\section{EXPLANATION OF PLATE VI.}

Fig. 12. Humerus $\frac{1}{3}$. Right side.

Fig. 13. Scapula $\frac{1}{3}$. Right side.

FIG. 14. Coracoid $\frac{1}{3}$. Right side.

FIG. 15. Pubis $\frac{1}{3}$. Right side.

FIG. 16. Ischium ł. Right side.

FIG. 17. Ilium $\frac{1}{2}$. Right side (taken from smaller specimen).

FIG. 18. Femur $\frac{1}{3}$. Left side.

Fig. 19. Rib head 1. (Taken from smaller specimen.) 


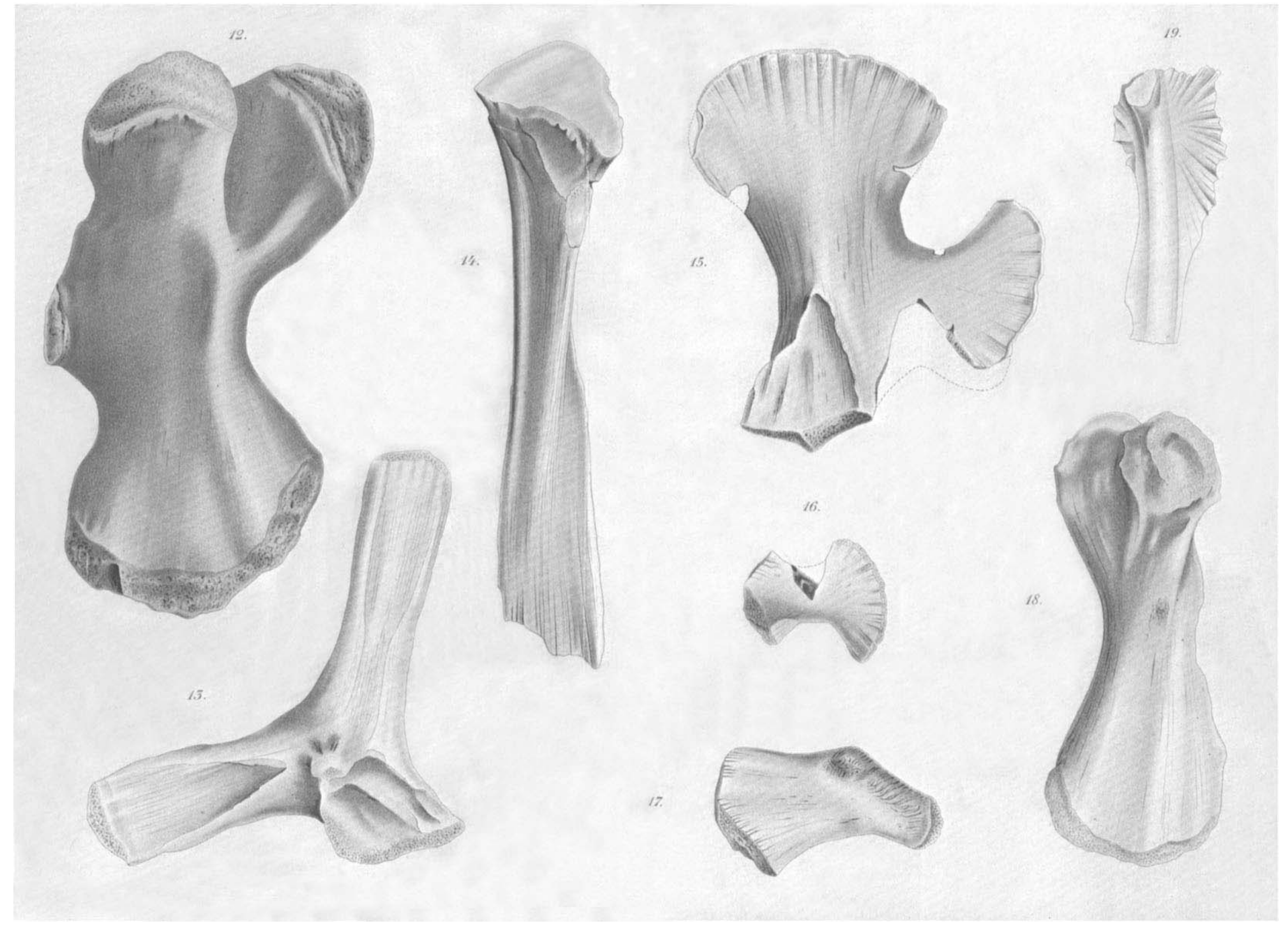

